УДК: 616-036.21:378

DOI: https://doi.org/10.18485/fb_covid19.2020.ch13

\title{
ПАНДЕМИЈСКА КРИЗА И УНИВЕРЗИТЕТ
}

\author{
проф. др Жељко Бралић 1 , \\ проф. др Љубинка Катић²
}

Апстракт: Пандемија изазвана глобалним ширењем инфекције вируса ковид 19, без стварног преседана у модерној историји, представљала је и још увек представља драматичан и по току и последицама незапамћен изазов у међународним, националним и локалним оквирима. У овом тексту аутори ће покушати да презентују и анализирају утицај пандемијске кризе на универзитетско окружење, полазећи од става да је васпитно-образовни систем, укључујући и високо школство, увек представљао значајан елемент критичне инфраструктуре; дакле, један од битних и најбитнијих друштвених ресурса чије функционисање има приоритетни значај за опстанак и репродукцију сваке друштвене заједнице. Нарочито ће у складу са доступним информацијама и изворима који се односе на глобалну кризу која је још увек у току бити представљени неки аспекти, покушаји и активности универзитета у Кини, као земљи која се прва суочила са епидемијом, а такође ће представити налазе из извештаја Међународне асоцијације универзитета који се односе на кризно реаговање светских универзитета у јеку пандемијске кризе. Посебну пажњу у средишњем делу рада посветиће онлајн настави као покушају системског и глобалног одговора на кризну ситуацију. Онлајн настава се великом броју универзитета наметнула као могућност одржавања основне наставне делатности универзитета у времену пандемијске кризе и строгих епидемиолошких мера социјалног дистанцирања и ограничавања кретања и контаката. Ова могућност је реализована као нужна и једино могућа у задатим околностима, с тим што су и приступи и реализација неуједначени и релативно произвољни, а објективне оцене о квалитету онлајн наставе у датим околностима тек се очекују, док се пандемијска криза продужава.

Кључне речи: пандемија, криза, универзитет, настава, онлајн настава.

\footnotetext{
1 Универзитет у Београду, Факултет безбедности; e-mail: zeljko.bralic@fb.bg.ac.rs
}

2 Универзитет у Београду, Факултет безбедности; e-mail: ljubinka.katic@fb.bg.ac.rs 


\section{УВод}

Пандемија изазвана вирусом ковида 19 изазвала је вишеструку и вишеслојну глобалну кризу незабележених размера и облика, пореметила је нормално функционисање на свим нивоима, од глобалног и регионалног до локалног и персоналног, и то практично у свим важним аспектима живота у савременом свету. Иако је порекло саме актуелне глобалне кризе у здравствено-медицинском сектору, пандемија је изазвала дубоке потресе и поремећаје који тешко погађају економске активности, трговину и саобраћај, друштвене токове и кретања, политичке и међународне односе, а велики поремећаји су настали и у областима културних, васпитно-образовних и спортских делатности. Васпитно-образовни системи, због својих специфичности које подразумевају велики број ученика, студената и особља који су у свакодневном блиском контакту у ванредним околностима, каква је актуелна пандемија, представљају изузетно велики здравствено-епидемиолошки ризик. Такви системи су се од самог почетка пандемијске опасности нашли у кризној ситуацији која је захтевала брзо и флексибилно реаговање, и то у околностима које су и за глобалне и за националне оквире практично без преседана. Анализе и истраживања која се односе на различите нивое и делове школских и васпитно-образовних система у извесном броју су већ објављена, мада у наредном периоду тек треба очекивати обиље различитих научних и стручних радова који ће се бавити пандемијском кризом у васпитању и образовању.

У овом раду покушаћемо да прикажемо неке до сада познате покушаје и искуства у реаговању на пандемијску кризу у високошколском образовању. Постојећа искуства и информације о реаговању универзитета на кризу изазвану пандемијом дају основа и за неке прелиминарне закључке и препоруке за поступање у наредном периоду, будући да је пандемијска криза и даље у току и да се може очекивати да потраје и наредних месеци (ако не и година); дакле, много дуже него што се у стручним круговима првобитно процењивало.

\section{ИСКУСТВА КИНЕСКИХ УНИВЕРЗИТЕТА}

Зачеци будуће пандемије изазване ширењем вируса ковида 19 јавили су се у Кини у граду Вухану (провинција Хубеј), у децембру 2019. године, да би се епидемија за само тридесет дана из Вухана проширила на Народну Републику Кину у целини. Због брзине ширења епидемије, уз интензивну географску експанзију и нагли и брзи пораст броја случајева инфекције, овакав догађај је био до тада незапамћен и 
у почетку је као крајње драматичан убрзано преоптеретио јавноздравствене службе и капацитете, „посебно у граду Вухану и провинцији Хубеј“.3

Ширење информација из Кине ка глобалној јавности о новој заразној болести било је, супротно негативним оценама у извесним круговима, релативно брзо и ефикасно. Светска здравствена организација обавештена је о избијању епидемије 31. децембра 2019. године, у тренутку када је забележено 27 случајева (без иједног фаталног исхода до тада), док је у избијању епидемије SARS 2002-2003. године одговарајућа информација уследила након 300 забележених случајева, уз 5 умрлих пацијената. ${ }^{4}$ Узрочник заразе (нови коронавирус 2019, 2019-nCoV) идентификован је већ 7. јануара5, врло брзо је секвенциран његов геном, који је глобално прослеђен 13. јануара.

Уз затварање града Вухана и још 15 других градова (23. и 24. јануара) кинеске власти су од 1. фебруара наложиле и „продужетак празника“ који је подразумевао забрану похађања школа и радних места. ${ }^{6}$ Забрана се продужила на наредне недеље и месеце, што је целокупан васпитно-образовни и школски систем Кине, укључујући и високо образовање, приморало на брзу и масовну преоријентацију на наставу, образовање и учење у новим и до сада незабележеним околностима, које су захтевале да школске и образовне институције функционишу уз минимум или без икаквог контакта, сусрета и окупљања.

У Кини је, дакле, раније него у другим земљама дошло до поремећаја у редовном функционисању васпитно-образовног и школског система, укључујући и универзитете који су, суочени са здравственом кризом раније невиђених размера, реаговали релативно брзо, налазећи начина да и у новим околностима одрже и очувају своју образовну функцију, уз додатне традиционалне улоге и допринос у домену социјалних служби, научних истраживања и усавршавања стручњака. ${ }^{7}$

3 Zunyou Wu, Jennifer M. McGoogan, "Characteristics of and Important Lessons From the Coronavirus Disease 2019 (COVID-19) Outbreak in China: Summary of a Report of 72314 Cases From the Chinese Center for Disease Control and Prevention", The Journal of the American Medical Association, Vol. 323, No. 13, 2020, p. 1240. Текст је објављен 7. априла на основу извештаја Кинеског центра за контролу и превенцију болести, објављеног 11. фебруара 2020.

4 Op. cit., p. 1240, 1242. Запажамо да аутори на два места у графикону и табели („Wuhan Health Commission alerts National Health Commission and China CDC, and WHO is notified", 1240; "China reports a cluster of cases of pneumonia with unknown etiology in Wuhan to WHO“, 1241) као датум обавештавања Светске здравствене организације наводе 31. децембар 2019, док у тексту на стр. 1241 помињу 3. јануар 2020. Други извори, укључујући и Светску здравствену организацију, потврђују да је у питању 31. децембар. (WHO, Novel Coronavirus (2019-nCoV), Situation Report - 1, 21. january 2020., p. 1; )

5 Chuanyi Wang, Zhe Cheng, Xiao-Guang Yue, Michael McAleer, „Risk Management of COVID-19 by Universities in China“, Journal of Risk and Financial Management, Vol 13, No 36, 2020, p. 1. Рад је објављен 19. фебруара.

${ }^{6}$ Zunyou Wu, Jennifer M. McGoogan, op. cit., p. 1240.

7 Chuanyi Wang, Zhe Cheng, Xiao-Guang Yue, Michael McAleer, op. cit., p. 2. 
Већ у почетку епидемијске кризе кинески универзитети су преко својих алумни заједница и група организовали канале подршке за прикупљање материјалне помоћи, нарочито за провинцију Хубеј, тако да су потребни материјали и помоћ стизали из Немачке, Аустралије, САД. ${ }^{8}$

У научноистраживачком пољу универзитетски истраживачки тимови, осим подршке клиничким тимовима, остварили су и значајне резултате који су допринели ширењу научних сазнања о зарази, њеном изазивачу и ширењу епидемије. То је, између осталог допринело сазнањима да постоји значајна подударност у соју вируса изолованог код егзотичне и ретке животиње панголина и вируса који проузрокује епидемију код људи; такође су универзитетски тимови учествовали у пројектовању и производњи првих тестова, укључујући и релативно прецизне брзе тестове за детекцију вируса за само 15 минута. ${ }^{9}$

C друге стране, одржавање редовног наставног процеса на универзитетима у великој мери је морало да буде поремећено, одложено и/или модификовано, што се у кинеским оквирима мора сагледати као изузетно велико искушење, које је захтевало посебно ангажовање наставника и особља, као и флексибилна решења и специфичне мере за функционисање универзитетске наставе, образовања и учења у кризним околностима. Ова решења и мере морале су обезбедити очување наставног и образовног процеса за чак 33.600.000 кинеских студената. ${ }^{10}$

Већ у релативно раној фази епидемијске кризе кинески универзитети су се ослонили на могућности које пружа савремена технологија, првенствено на онлајн наставу преко различитих платформи и апликација, с тим што су већ почетна искуства указивала на значајне проблеме и изазове са којима се може суочити универзитет када се мора нагло, брзо и неочекивано ослонити на моделе онлајн образовања и наставе. Неопходно је, између осталог, да се наставници, навикли на традиционалну наставу, релативно брзо и успешно прилагоде новим околностима, приступима, методама и средствима, да би успели да постигну адекватне резултате наставе и исходе учења. Ово принципијелно питање са којим се након кинеских колега суочавао и суочава и глобални универзитетски свет, заиста може значајно „да погоди квалитет терцијарног образовања“, што отвара питање о „незадовољавајућој примени информатичке технологије у разрешавању кризе“. 11

${ }^{8}$ Ibid.

9 Ibid. У овим значајним истраживањима учествовали су истраживачки тимови са Универзитета у Вухану, Пољопривредног универзитета Јужне Кине, Војне академије Народноослободилачке армије НР Кине, Војномедицинског истраживачког института, шангајског Ђијатонг универзитета (Shanghai Jiaotong University), Тјанђин универзитета (Tianjin University) и других универзитетских и научноистраживачких установа.

$10 \mathrm{Ibid}, \mathrm{p} .3$. Од ових 33,66 милиона, више од $26 \%$ (8,83 милиона) су студенти који студирају изван своје провинције, па им због забране путовања и кретања њихов универзитет у јеку нужних и строгих епидемиолошких мера није био ни физички доступан.

11 Op. cit., p. 6, p. 1. 
У сваком случају, на кинеским универзитетима се догађала незабележена масовна „миграција“ са традиционалне директне наставе на онлајн образовање, будући да је кинеска влада препоручивала и захтевала да се поучавање и учење настави без прекида. ${ }^{12}$ На позив Министарства образовања Кине универзитети су већ у фебруару установили мрежу подршке и онлајн мрежне платформе за систематску обуку и техничку подршку наставницима који се морају преоријентисати на онлајн наставу, што је требало да ублажи или спречи претходно поменуте тешкоће, као и застоје у наставном и образовном процесу. ${ }^{13}$

Универзитети су спремно и брзо успостављали и реализовали планове за примену онлајн наставе и учења, организовали одговарајуће платформе, обезбеђивали квалитетне изворе за општеобразовне и стручне садржаје који су студентима обезбедили да у посебним и ванредним околностима, и поред отказане редовне наставе, ипак успешно наставе са релативно квалитетним учењем. ${ }^{14}$

Сматрамо да је посебно занимљив још један од аспеката реакције „многих водећих кинеских универзитета“ на епидемијски кризу, а тај аспект подразумева „изузетну иницијативу у прихватању друштвене одговорности, отварање платформи за наставу друштву без накнаде, и тако су поделили више од десет хиљада високо квалитетних садржаја и курсева."15 Ова иницијатива, заснована на специфичној примени тзв. универзитетске екстензе у ванредним околностима, где се универзитет укључује у управљање кризом тиме што ширем друштвеном окружењу обезбеђује образовне садржаје и могућности учења, представља позитиван пример одговора на кризну ситуацију која је захватила друштво у целини. Обезбеђивање бесплатних образовних садржаја високошколског нивоа овде се схвата као добродошла акција која и грађанима и јавности изван универзитетских кругова пружа могућност да се са кризом, стресом и страхом (у условима епидемијске опасности и строгих епидемиолошких мера забране кретања и ускраћивања социјалних контаката) избори на позитиван и користан начин, учењем и усавршавањем, савладавањем различитих садржаја и програма, задовољавањем својих интересовања и интелектуалне радозналости. Тако се и фрустрација и бројна ограничења која намеће борба против епидемије могу ублажити тиме што ће се многи грађани укључити у образовне акције за које у редовним околностима нису имали могућности.

12 Wei Bao, „COVID-19 and online teaching in higher education: A case study of Peking University“, Human Behavior and Emerging Technologies, Vol. 2, No. 2, 2020, p. 1.

13 Ibid, p. 3.

14 Mengquing Kan, Jihe Zhou, „How Do Colleges and Universities Respond to Covid-19: The Experience of Chengdu Sport University“, Asia Pacific Journal of Public Health, Vol. 32, No. 4, 2020, p. 2.

15 у овом погледу посебно су се истакли мрежа за наставу пекиншког универзитета (Peking University Lecture), Онлајн школа Цингхуа универзитета (Tsinghua University Online School), Платформа за учење страних језика пекиншког Универзитета за међународне студије (Beijing Foreign Studies University, Foreign Language Online Learning Platform), и други. Ibid. 


\section{ГЛОБАЛНА КРИЗА, ГЛОБАЛНЕ ПОСЛЕДИЦЕ}

Будући да је Светска здравствена организација 11. марта 2020. и званично прогласила пандемију заразне респираторне болести изазване новим коронавирусом, до 1. априла глобално ширење инфекције довело је до појаве која није забележена у модерној историји - 43\% светског становништва $(3,4$ милијарде људи) нашло се у посебној ситуацији живота у изолацији или карантину, што је обухватало преко 80 земаља. То је довело и до тада незабележених поремећаја високог образовања. 16

О дубини и обиму кризе сведоче драматични подаци које наводи UNESCO: на дан 1. априла школе и универзитети су били затворени у 185 земаља, а то се односило на преко 1,5 милијарди $(1,542.412 .000)$ ученика и студената, или 89,4\% укупног броја; почетком маја још увек су биле затворене образовне установе у 177 земаља (тиме је било погођено 1,268.164.088 ученика и студената, 72,4\% уписаних). ${ }^{17}$

На новонасталу кризну ситуацију, између осталих, реаговале су и све релевантне међународне асоцијације, укључујући и оне које окупљају, повезују и подржавају универзитете на глобалном плану. У овом тексту посебну пажњу посветићемо истраживањима, иницијативама и препорукама Међународне асоцијације универзитета (International Association of Universities, основана под окриљем UNESCO-а 1950. године), која се оправдано сматра водећом асоцијацијом универзитета у глобалним оквирима.

Међународна асоцијација универзитета се у сарадњи са бројним партнерским организацијама и експертима од самог почетка актуелне кризне ситуације укључила у праћење, прикупљање искустава и информација, успостављање мреже подршке високообразовним установама, организовање анкета и истраживања, објављивање извештаја и препорука за прилагођавање универзитетских установа новонасталим условима глобалне пандемијске кризе.

Асоцијација је планирала три обимна истраживања утицаја епидемије на високо образовање у светским размерама, а већ у мају су објављени резултати, анализе и препоруке на основу првог круга истраживачког пројекта (други круг истраживања планиран је за јесен, а трећи за наредну годину).

Објављени извештај заснива се на анкетном истраживању и одговорима које су послале 424 високообразовне установе из 109 земаља (и две посебне кинеске административне области - Хонг Конг и Макао), подељених на четири светска региона: (1) Африка, (2) обе Америке, (3) Азија и Пацифик, (4) Европа. 18

16 Giorgio Marinoni, Hilligje van't Land, „The Impact of COVID-19 in Global Higher Education“, International Higher Education, No. 102, Special Issue, 2020, p. 7.

17 Giorgio Marinoni, Hilligje van't Land, Trine Jensen, The Impact of Covid-19 on Higher Education around the World: IAU Global Survey Report, International Association of Universities, Paris, 2020, p. 8.

18 Ibid, p. 11. 
Прикупљање података и одговора на анкетни упитник трајало је од 25. марта до 17. априла; анкета је претежно нудила вишеструке понуђене одговоре, с тим што су постојала и два отворена питања, и захваљујући одговорима на та питања, било је могуће утврдити неке кључне трендове. ${ }^{19}$ Упитник је био тројезични, тако да су одговори могли да се пруже на енглеском, француском и шпанском језику. Скоро две трећине одговора дато је на енглеском језику (64\%), а на шпанском само 8\%.

Основно и почетно питање гласило је:

Како је пандемија ковида 19 утицала на вашу институцију?20

\begin{tabular}{|l|l|}
\hline Отворена као и обично, без посебних мера & $1 \%$ \\
\hline Отворена као и обично, али уз ограничења кретања & $10 \%$ \\
\hline Делимично отворена, уз знатне поремећаје & $30 \%$ \\
\hline Све активности у кампусу обустављене, установа потпуно затворена & $59 \%$ \\
\hline
\end{tabular}

Убедљиво највећи проценат установа које су у потпуности затворене налазио се у Африци (77\%), мада је у време прикупљања одговора Африка званично имала најмањи број пријављених случајева заразе у свету; претпоставља се да је у питању мера превенције која је донета од стране руководства установа или су их на то својим одлукама обавезале националне владе. У том смислу, афрички универзитети су превентивне мере предузимали раније (могуће и благовременије) него већина светских универзитета.

Велика већина анкетираних универзитета (91\%) одговорила је да поседује успостављену одговарајућу инфраструктуру за лако преношење нових информација студентима и особљу, с тим што је чак $34 \%$ афричких универзитета без овакве критичне инфраструктуре (код осталих универзитета инфраструктуру поседује између 97 и 99\%). Пошто је велики проценат афричких универзитета затворен, то указује на веома штетну ситуацију у којој велика већина студената у потпуности губи сваки контакт са својим универзитетом докле год су кампуси и универзитети затворени. С друге стране, мада је у Европи универзитетска структура за комуникацију на високом нивоу (97\%), ипак су и тамо пријављене тешкоће у токовима комуникације и информација; важније од саме инфраструктуре може бити „планирање и управљање јасним токовима комуникације да би се обезбедило неопходно вођење у кризама обележеним високим нивоом неизвесности“. 21

19 Ibid, p. 10. Отворена питања нису била обавезна, али је ипак 75\% испитаника пружило одговоре; испитаници су углавном били ректори, декани, професори, руководиоци и други функционери универзитета.

20 Сви подаци који су у извештају представљени графиконима у нашем тексту су адаптирани, одговори су делимично скраћени и приказани у табелама (прим. аут.).

${ }^{21}$ Ibid, p. 17. 
Сматрате ли да ће ковид 19 утицати на број студената који ће се уписати у следећој школској години? 22

\begin{tabular}{|l|l|}
\hline Не & $22 \%$ \\
\hline Да, али само на број међународних студената & $27 \%$ \\
\hline Да, али само на број локалних студената & $5 \%$ \\
\hline Да, на број свих студената & $46 \%$ \\
\hline
\end{tabular}

Чак трећина афричких универзитета није очекивала да ће криза негативно утицати на број уписаних студената, док су универзитети у региону Азије и Пацифика у великом проценту (85\%) сматрали да ће тај утицај бити веома велик и врло штетан.

На питање да ли су чланови вишег менаџмента или факултета консултовани од стране јавности или владиних званичника у контексту јавних политика везаних за ковид 19, скоро две трећине универзитета (65\%) одговорило је потврдно, а само 17\% негативно, што упућује на закључак да се светске владе у солидној мери ослањају на експертизу својих универзитета и у кризним ситуацијама каква је активна пандемија.

У питању које се тиче помоћи државне и/или просветне власти универзитетима у савладавању актуелне кризе $48 \%$ универзитета одговара да је таква помоћ најављена (у двоструко мањем проценту одговор је негативан, 24\%; у 28\% одговор је не знам), с тим што су најављене различите врсте помоћи, разврстане у неколико категорија. ${ }^{23}$

\begin{tabular}{|l|c|}
\hline Подршка за регуларно окончање академске године & $67 \%$ \\
\hline Финансијска подршка за очекиване губитке у приходима & $13 \%$ \\
\hline $\begin{array}{l}\text { Саветовање о пропуштеним кредитима за курсеве који су неопходни за } \\
\text { напредак / дипломирање }\end{array}$ & $31 \%$ \\
\hline Остало & $29 \%$ \\
\hline
\end{tabular}

Највећа подршка државне и просветне власти најављена је универзитетима у Европи (53\%), а најмања у Африци (39\%).

Више од половине универзитета (54\%) сматра да је ковид 19 утицао на сарадњу универзитета са другим универзитетима и партнерским организацијама и асоцијацијама; према очекивањима, претежно је оцењено да је тај утицај био штетан и негативан.

\footnotetext{
22 Ibid, p. 18, fig. 7.

23 Ibid, p. 20, fig. 10.
} 
Како је ковид 19 утицао на вашу сарадњу / партнерства?24

\begin{tabular}{|l|l|}
\hline Ослабио ју је, морали смо да усмеримо ресурсе на локална питања & $51 \%$ \\
\hline Ојачао ју је, координисали смо напоре у одговору на ковид 19 & $16 \%$ \\
\hline $\begin{array}{l}\text { Створио је нове прилике за сарадњу са партнерским установама (нпр. } \\
\text { виртуална мобилност, дељење ресурса итд.) }\end{array}$ & $31 \%$ \\
\hline
\end{tabular}

Једна од најтеже погођених области глобалне универзитетске заједнице, узимајући у обзир магнитуду и глобалне размере пандемијске кризе и свеобухватних, нагло увођених, и оштрих епидемиолошких мера, које су обухватиле готово све земље света - јесте свакако и међународна студентска мобилност. Очекивани одговор велике већине универзитета (чак 89\%) гласи да ковид 19 јесте утицао на међународну мобилност студената, и то на различите начине.

Какав је утицај ковида 19 на међународну студентску мобилност?25

\begin{tabular}{|l|l|}
\hline Међународни студенти су затечени у нашој установи & $47 \%$ \\
\hline Наши студенти су затечени у страним установама & $37 \%$ \\
\hline Међународни студенти су одлучили да прекину студије & $39 \%$ \\
\hline Размена студената је отказана са неким земљама & $43 \%$ \\
\hline Целокупна размена студената је отказана & $33 \%$ \\
\hline
\end{tabular}

Уместо „физичке“ мобилности студената, неки универзитети су чинили напоре да успоставе и утврде одговарајуће и доступне алтернативе, укључујући и „виртуелну мобилност“.

Да ли је ковид 19 подстакао алтернативе физичкој мобилности студената?26

\begin{tabular}{|l|l|}
\hline Не & $34 \%$ \\
\hline Да, повећали смо виртуелну мобилност и/или сарадњу у онлајн учењу & $60 \%$ \\
\hline У развоју & $1 \%$ \\
\hline Планирамо и разматрамо њихов развој & $4 \%$ \\
\hline Не знам & $1 \%$ \\
\hline
\end{tabular}

Неочекивана је и занимљива (свакако и штетна) чињеница да универзитети у немалом проценту (27\%) нису имали (немају) планове за поступање у ванредним ситуацијама (contingency plans), па се мора очекивати да ће пандемијска криза нужно унапредити свест и спремност великог броја универзитета за суочавање са

\footnotetext{
24 Ibid, p. 21, fig. 11.

25 Ibid, p. 27, fig. 15.

26 Ibid, p. 29, fig. 17.
} 
различитим врстама криза. ${ }^{27}$ Такође се у складу са појачаним интересовањем које пандемијска криза изазива у глобалној јавности може очекивати да се и у студијским програмима светских универзитета уводе, проширују и унапређују садржаји и студије из области кризног менаџмента, кризног комуницирања, епидемиологије, вирусологије, имунологије итд.

Да ли постоје планови за поступање у ванредним ситуацијама?28

\begin{tabular}{|l|l|}
\hline Не & $27 \%$ \\
\hline Да, постоје у нашој установи & $34 \%$ \\
\hline Да, постоје у партнерској установи у иностранству & $3 \%$ \\
\hline Да, постоје и у нашој и у партнерској установи & $36 \%$ \\
\hline
\end{tabular}

Једна од основних преокупација светских универзитета било је очекивано и предстојеће организовање испитних активности у наступајућем периоду.

Да ли очекујете да ћете бити у могућности да спроведете испите

онако како је за овај семестар планирано?29

\begin{tabular}{|l|l|}
\hline Да, као и обично & $6 \%$ \\
\hline Да, али уз нове мере & $45 \%$ \\
\hline Да, али само делимично, део ће бити одложен & $14 \%$ \\
\hline Не, већина испита су у ризику да буду одложени & $13 \%$ \\
\hline Не, сви испити су обустављени & $11 \%$ \\
\hline Не знам & $11 \%$ \\
\hline
\end{tabular}

Већина универзитета је одговорила да су (биле) у току расправе о поменутом проблему са испитима, а познато нам је да су се испити на светским (као и на нашим) универзитетима након објављивања извештаја одржали (и одржавају се) уз различите тешкоће и уз примену прилагођених епидемиолошких мера, у складу са актуелним јавноздравственим препорукама, и уз посебне мере и облике полагања испита, ванредне термине и рокове полагања. Све то универзитетску заједницу (студенте, наставно и ненаставно особље) излаже повећаним напорима и захтевима да се у свакој фази епидемије и у специфичним околностима пронађу и реализују одговарајућа решења за реализацију испитних активности уз минимализовање здравственог ризика којем су изложени студенти, наставници и универзитетске службе.

Један од трендова, примећен и на српским универзитетима, јесте (барем привремено) одустајање од усменог испитивања и готово масовна

27 У извештају се значај овог проблема једва помиње, јер под међунасловом Improving crisis management readiness (p. 38) једва да постоје три реченице текста. Насупрот томе, ми сматрамо да би управо ту морало бити примарно тежиште оваквих анализа, евалуација и препорука. (Прим. аут.)

${ }^{28}$ Ibid, p. 28, fig. 16.

${ }^{29}$ Ibid, p. 30, fig. 18. 
преоријентација на писмене провере знања. Брзо и нагло напуштање устаљеног начина испитивања и прелазак на испитне тестове представља потенцијални проблем и за наставнике и за студенте. Наставници који никада нису припремали тестове за проверу знања нису имали времена да се о том процесу темељније обавесте и да стекну нужне компетенције за тестирање, а ни студенти нису били у могућности да се упознају са изменама у организацији и реализацији испита, нити да се припреме за нови начин провере знања и оцењивања. Зато сматрамо да је тестирање као начин провере знања и извођења испита (тамо где није било редовна пракса) још једно од изнуђених (и могуће привремених) решења, чију оправданост треба проверавати, а евентуалне негативне последице треба пажљиво пратити да би се успоставио квалитетан и ваљано припремљен систем и механизам објективне провере знања и оцењивања.

Утврђено је да пандемија изазвана вирусом ковид 19 свакако има негативне последице и у области научноистраживачке делатности светских универзитета.

Како је ковид 19 утицао на истраживања у вашој установи?30

\begin{tabular}{|l|c|}
\hline Научна истраживања су отказана или одложена & $81 \%$ \\
\hline $\begin{array}{l}\text { Међународна путовања су отказана (нема више гостујућих професора, } \\
\text { нити одлазака у иностранство) }\end{array}$ & $83 \%$ \\
\hline $\begin{array}{l}\text { Научноистраживачки пројекти су у опасности да не буду успешно } \\
\text { окончани }\end{array}$ & $52 \%$ \\
\hline Сва научна истраживања у нашој установи су заустављена & $2 \%$ \\
\hline
\end{tabular}

Неке установе (41\%) су биле укључене у различита научна истраживања о ковиду 19 , а већи проценат установа (86\%) сматрао је да њихови истраживачи на неки начин учествују у реализацији јавне политике у односу на борбу против ковида 19.

Што се тиче јавног ангажовања универзитетских установа, 45\% њих је сматрало да је ковид 19 повећао тај ангажман (31\% сматра да га је умањио). Већина универзитета (58\%) је предузимао неке активности у контексту ковида 19, а те активности су разврстане у неколико категорија.

Које активности се предузимају ${ }^{31}$

\begin{tabular}{|l|r|}
\hline Наша универзитетска клиника обезбеђује негу погођенима болешћу & $22 \%$ \\
\hline Наши студенти и особље обезбеђује мобилну помоћ погођенима болешћу & $28 \%$ \\
\hline Обезбеђујемо медицинску негу и подршку & $40 \%$ \\
\hline Развијамо иницијативе за научну комуникацију & $49 \%$ \\
\hline Интензивирамо сопствене друштвене активности & $52 \%$ \\
\hline Остало & $27 \%$ \\
\hline
\end{tabular}

30 Ibid, p. 32, fig. 21.

31 Ibid, p. 36, fig. 24. 
Многи анкетирани универзитети у јеку саме пандемијске кризе извештавају да су врло забринути и због финансијских импликација кризе на њихове установе, због могућег пада броја уписаних студената, којег су се прибојавали, а многи су већ приметили непосредне и негативне финансијске последице, док је вероватно оправдано што многи очекују дугорочно лошу економску ситуацију у ширим оквирима, дубоку економску рецесију са врло негативним последицама, које ће укључити и мањи број студената у будућности итд. Чак су и државни универзитети очекивали смањивање финансирања од стране државе у скоријој будућности, што ће бити проузроковано финансијском кризом која очекује све земље. 32

\section{НАСТАВА НА ДАЉИНУ: ИЗЛАЗ У СЛУЧАЈУ НУЖДЕ ИЛИ ДРАГОЦЕНА ПРИЛИКА}

У новонасталим околностима готово целокупна глобална универзитетска заједница је у изузетно кратком временском периоду морала да пронађе доступан и безбедан начин (или начине) за одржавање барем прихватљивог и одрживог нивоа процеса поучавања, учења и образовања. Врло брзо се тежиште управљања кризом у појединачним националним и глобалним оквирима помера ка различитим облицима, платформама и алатима за наставу на даљину, а првенствено ка онлајн настави. Многобројне анализе, оцене, па и полемике о онлајн настави на светским универзитетима у време пандемије ковида 19 очекују се у наредном периоду, а извештај Светске асоцијације универзитета је веома значајан рани извор прелиминарних и свежих података прикупљених у јеку пандемијске кризе.

Како је ковид 19 утицао на наставу и учење?33

\begin{tabular}{|l|l|}
\hline Није утицао & $2 \%$ \\
\hline Непосредно поучавање је замењено поучавањем и учењем на даљину & $67 \%$ \\
\hline $\begin{array}{l}\text { Већина активности је тренутно одложена, али установа ради на развоју } \\
\text { решења за наставак наставе и учења путем дигиталних или средстава за } \\
\text { самостално учење }\end{array}$ & \\
\hline Настава је отказана & $7 \%$ \\
\hline
\end{tabular}

Међу 2\% установа које „нису биле погођене“ (укупно 7 универзитета), четири су тзв. виртуална универзитета, која редовно функционишу преко онлајн платформи. Забрињавајуће је да чак једна трећина установа није била у могућности да се преоријентише на онлајн наставу, мада је наведено да углавном и оне у тренутку анкетирања раде на проналажењу одговарајућих решења за наставак наставе онлајн каналима. ${ }^{34}$ O значајним напорима да се изврши

\footnotetext{
32 Ibid, p. 38.

33 Ibid, p. 23, fig. 13.

34 Ibid, p. 23. Морамо напоменути да је примећено да неке од установа нису анкету схватиле сасвим адекватно (или озбиљно), па има случајева да (две) установе
} 
реорганизација и прелазак на онлајн наставу, образовање и учење - сведочи и приметан скок у броју објављених научних и стручних радова посвећених доприносу онлајн наставе превазилажењу пандемијске кризе у школству и на универзитету. 35

У наредном периоду биће од великог значаја евалуација искустава и постигнућа, квалитета, свеукупног утицаја и домета својеврсне „кризне дигитализације високог образовања" која је у току и која се наставља због продужавања пандемијске ситуације у целом свету. ${ }^{36}$ Светска асоцијација ће, без сумње, у најављеним и раније поменутим фазама (другој и трећој) истраживачког пројекта пружити одговарајући приказ, анализу и оцену ове до сада сигурно најмасовније акције кризне, хитне и изнуђене глобалне реформе високог образовања. У наредном периоду светска академска јавност мора помно пратити најављене извештаје, анализе и оцене, између осталог и због очигледне чињенице да се у размени искустава, научних и стручних анализа и евалуација релевантних светских организација могу и морају тражити препоруке, смернице и сугестије које упућују и на квалитетне (квалитетније) обрасце поступања у текућој и свакој будућој кризној ситуацији глобалних размера.

Може се напоменути да је у Европи прелазак на онлајн наставу био наизглед најмасовнији и најбржи (85\%), док је проценат у Африци знатно нижи (29\%). У овом погледу универзитети у Африци су најтеже погођени, јер је чак 43\% универзитета било у фази у којој су предавања одложена док се траже решења, а у $24 \%$ случајева настава је отказана (у свим осталим регионима тај проценат је $3 \%$ ). ${ }^{37}$

У сваком случају, нагли и неочекивани (може се рећи и неприпремљени) кризни прелазак на онлајн наставу у сваком смислу је представљао велико искушење за светску академску заједницу, па анализе тих околности, постигнућа и грешака очекују се у наредним месецима и годинама. Онлајн поучавање, учење и образовање у контексту пандемијске кризе и наглог дисконтинуитета редовних наставних активности, између осталог, доноси изазове који се у извештају анализирају у три значајна сегмента: (1) техничка инфраструктура и доступност, (2) компетенције и педагогија учења на даљину, (3) област студија. ${ }^{38}$

Текућа глобална пандемијска криза нарочито снажно подржава статус и значај интернета као критичне инфраструктуре. Будући да је више него јасно да је онлајн настава неостварива и неодржива уколико не постоји довољно развијена

извештавају да је њихов кампус затворен, а да истовремено тврде да поучавање и учење није угрожено. Светска асоцијација није у овој ситуацији била у могућности да тражи додатне информације, нити да разјашњава контрадикторности у одговорима универзитета. Подаци у извештају могу се ипак због довољно великог узорка сматрати углавном солидним и квалитетним, узимајући у обзир кризне и ванредне околности у којима је организовано анкетирање и изванредно брза припрема извештаја. (Прим. аут.)

35 Ibid.

36 Ibid.

37 В. табелу, Ibid, p. 24.

38 Ibid, p. 24-26. 
инфраструктура, а пре свега могућност повезивања студената са интернетом од куће, свака реализација наставе на даљину у виду онлајн поучавања и учења остаје немогућа. Због тога је, нарочито у Африци, у условима карантина и/или друштвеног дистанцирања као препоручених или обавезних епидемилошких мера, код многих универзитета дошло до тешког поремећаја или обуставе наставних активности, што је даље довело у питање и само елементарно завршавање школске године за многе студенте. ${ }^{39}$ Међутим, чак и у земљама са солидном и масовно доступном интернет инфрастуктуром то није нужно значило да су универзитетима били доступни технички предуслови, средства и алати за оптимизовање учења на даљину (то је, између осталог, изискивало непланиране трошкове за средства, опрему и лиценце). 40 Уочено је да и у оквирима истих установа постоји неједнакост у погледу могућности за приступ интернету између различитих студената, што нас суочава са обавезом да у евалуацији било каквих домета и постигнућа онлајн наставе морамо водити рачуна да доступност овог вида наставе мора бити обезбеђена свим студентима, јер би иначе они студенти који су због било којих разлога ускраћени за могућност квалитетног праћења онлајн наставе били изложени једном новом виду дискриминације. ${ }^{41}$

Одређени број испитаника је нагласио да је за („неосетни“) прелазак на даљинско поучавање и учење потребан нови педагошки приступ (или приступи - у оригиналу different pedagogy, дословно „другачија педагогија“), а то запажање отвара низ питања и дилема које у самом извештају нису могле бити разрешене, а верујемо да ни у будућим истраживањима, анализама и расправама тешко може доћи до коначних разрешења и било каквог научног и стручног консензуса о овим питањима. Извештај само површно наводи упитан ниво спремности наставника за брзо суочавање са овим изазовом, уз готово успутну напомену коју ћемо навести у целини, јер сматрамо да су аутори извештаја (вероватно не сасвим свесно и намерно) у једној реченици у средини извештаја извели (по нашем мишљењу) најтачнији и вероватно најискренији закључак целокупног истраживања, свеукупне ситуације и самог извештаја:

Ипак, иако наставак образовања у највећем могућем обиму неће моћи да гарантује (обезбеди) исти ниво квалитета у поређењу са образовањем лицем у лице планираним за овај семестар, извештава се да је то ипак боље него да се образовање не обезбеди уопште. 42

Приметно је да општи тон извештаја осцилује између неутралног и благо оптимистичног, вероватно уз очекивања темељнијих анализа и оцена у наредним фазама истраживачког пројекта, али сматрамо да је ипак било могуће, као у претходном примеру, готово „између редова“ досегнути стварну магнитуду кризе

\footnotetext{
39 Ibid, p. 25.

40 Ibid.

41 Забележен је (само) један, али карактеристичан случај приступа решавању овог проблема, где је сама институција обезбеђивала и дистрибуирала техничке уређаје (таблете, телефоне), у покушају да избегне веће поремећаје наставног процеса. (Ibid.)

42 Ibid, подвлачење наше.
} 
и проблема у којима се заједно са свим аспектима живота у глобалним оквирима, брутално суочила и светска универзитетска заједница.

Један од показатеља проблема са наглим преласком с директне наставе на онлајн поучавање је и запажање да се тај процес код наставника често одвијао „учењем кроз праксу“ („learning by doing““”) или покушајима опонашања наставе лицем у лице, али на даљину. ${ }^{43}$

Што се тиче коришћења наставе на даљину код различитих области студија и наставних садржаја, примећене су увећане тешкоће примене онлајн наставе код изучавања неких наставних садржаја. Нарочито хумана и ветеринарска медицина, као и бројне дисциплине које се ослањају на лабораторијски рад и наставу, захтевају практичан рад који се не може надоместити поучавањем и учењем на даљину. Такође, у области студија уметности, дизајна, музике студенти нису у могућности да упражњавају неопходне практичне вежбе и облике наставе уколико немају приступ неопходној опреми која им је недоступна изван универзитета (самостално вежбање у кућним условима само је мали и недовољан аспект таквих студија и образовања).

У сваком случају, теоретска настава класичног предавачког типа показала се као најмање захтевна у ситуацији наглог и брзог преласка на онлајн средства и даљинску наставу. Међутим, бројне дисциплине и области студија, у којима оваква настава није доминантна (нити адекватна), тешкоће сигурно доводе до знатнијих поремећаја, па и (нај)већег укупног пада квалитета наставе уколико се поучавање и учење ограничи само на онлајн окружење. 44

И поред наведених проблема и негативних последица, у извештају се наглашавају и потенцијалне позитивне последице овог „неприпремљеног експеримента поучавања и учења на даљину“, јер је непланирана кризна ситуација, макар и силом прилика, морала допринети изградњи капацитета за обезбеђење даљинског поучавања и учења, употребом и тестирањем различитих средстава и алата, обучавањем и увежбавањем особља за онлајн наставу, што би у наредном периоду могло довести до унапређених могућности флексибилног учења и повећане спремности да се онлајн учење учини чак и интегралним делом студијских програма. 45

Сматрамо да је важно да нагласимо да се у случају претераног пребацивања тежишта наставе на средства, технологију и инфраструктуру може изгубити из вида непобитна чињеница да је онлајн настава пре свега наставни, педагошкоандрагошки и дидактички феномен, који се не сме посматрати као првенствено технолошка, медијска и информатичка делатност. Средства, канали и форма не смеју бити приоритетни у односу на суштину; дакле, онлајн настава је и даље

\footnotetext{
43 Ibid, p. 25.

44 Ibid, p. 26.

45 Ibid.
} 
првенствено настава, и дидактичка правила, принципи, методе итд. задржавају свој пуни значај у сваком наставном, па и онлајн окружењу.

У овом сегменту рада такође ћемо посебно (са становишта образовања одраслих и доживотног учења) нагласити да се „кризне“ и изнуђене свеукупне промене у приступима, разумевању и капацитетима за учење код куће (и рад од куће) потенцијално могу схватити као подстицај за масовније и успешније прихватање могућности и прилика за доживотно учење и образовање. 46

\section{УМЕСТО ЗАКЉУЧКА: КРИЗА У НАСТАВЦИМА}

Светска асоцијација универзитета је свој извештај објавила у мају (на основу података прикупљених у марту и априлу), а свет и светска академска заједница налазе се у продуженој пандемијској кризи чији крај се не може очекивати у скоријем времену.

Током првог великог таласа пандемије постојало је мноштво очекивања и предвиђања (чак и у стручној медицинској јавности) да ће криза јењавати са протоком времена, да he се незапамћено широко примењиваним епидемиолошким превентивним мерама број новозаражених постепено смањивати и да ће се на тај начин пандемија гасити и коначно замрети, нарочито у летњем периоду на северној хемисфери, да ће вирус постепено слабити и коначно ослабити и повући се, да ће се током лета свет постепено враћати у нормалан живот и сл.

Међутим, сва оптимистичка очекивања (па и прогнозе) била су очигледно претерана, свет се на прагу јесени и нове академске године налази у дубокој и широкој пандемији; попуштање строгих епидемиолошких мера (понекад и превише нагло), постепено отварање различитих привредних делатности, школства, универзитета донело је нов пораст броја заражених, па је отварање нове школске године на универзитетима у свету повезано и са многим непознаницама и ризицима.

Већина универзитета је уз велике напоре и посебне мере успела да на задовољавајући начин заврши наставни део школске године и испитне активности које су се морале реализовати пре почетка лета, а нови испити и приближавање почетка наставе у школској години отвара многа питања и недоумице уз недовољно јасне одговоре.

Многи универзитети, па и српски, у периоду делимичног и релативног „отварања“ пре летњег периода примењивали су онлајн и хибридне моделе наставе, као и

46 Ibid. У том смислу било би више него пожељно да се у што већој мери (и у кризним и у редовним околностима) јављају покушаји да се широј јавности бесплатно учине доступним различити образовни садржаји високошколског нивоа, какве смо помињали раније у овом раду. 
испитне активности које се готово у потпуности ослањају на писане провере знања, па се у недостатку поузданих предвиђања и прогноза очекује да се на сличан начин функционисање универзитета одвија и у наредном периоду.

Могуће је да у кризним околностима прикупљена искуства и стечене компетенције помогну да се неке тешкоће и испољене слабости ублаже и/или превазиђу, али није реално очекивати да се универзитет у скорој будућности приближи оптималном функционисању из редовних околности, јер већ вишемесечни напор и пренапрегнутост академске заједнице оптерећује ресурсе и стално доноси нове изазове и захтева нове реакције.

У наредном периоду, у кризи која траје и која ће трајати, биће више него неопходно да се универзитетска заједница од глобалне до националне, локалне и појединачне посвети, између осталог, и (само)критичкој евалуацији сопственог функционисања и поступања у кризи, што би морало да подразумева и објективно анализирање и мерење губитака и у квантитету и у квалитету образовања које је реализовано у кризном периоду. Уверени смо да академска заједница не може објективно да порекне да је до таквих губитака морало доћи (као што је, на пример, јасно и мерљиво опадање привредне активности у глобалним оквирима морало довести до великог пада стопе раста БДП, до рецесије у коју је свет закорачио и до светске економске кризе, која је по обиму и последицама вероватно много већа од претходне „велике“ кризе или „велике рецесије“ на крају прве деценије овог века).

Само на основу реалних показатеља и непристрасних закључака о озбиљним последицама и штети коју је пандемијска криза нанела високом образовању можемо у наредним месецима и годинама успешно надокнађивати оно што је (морало бити) пропуштено. Овакве закључке морамо и, надамо се, можемо очекивати од Међународне асоцијације универзитета, али и од свих нас који учествујемо у академском животу.

\section{ЛИТЕРАТУРА}

- Altbach, Philip G. de Wit, Hans, „Responding to COVID-19 with IT: A Transformative Moment?“, International Higher Education, No. 103, Summer Issue, 2020, pp. 3-5.

- Bao, Wei, „COVID-19 and online teaching in higher education: A case study of Peking University“, Human Behavior and Emerging Technologies, Vol. 2, Issue 2, 2020, pp. 13.

- Dunrong, Bie, Jin, Liu, „Temporary Action or New Model Experiment? Teaching at Chinese Universities in the Time of COVID-19“, International Higher Education, No. 102, Special Issue, 2020, pp. 18-20.

- Kan, Mengquing, Zhou, Jihe, „How Do Colleges and Universities Respond to Covid-19: The Experience of Chengdu Sport University“, Asia Pacific Journal of Public Health, Vol. 32, No. 4, 2020, p. 1-2.

- Marinoni, Giorgio, van't Land, Hilligje, „The Impact of COVID-19 in Global Higher Education“, International Higher Education, No. 102, Special Issue, 2020, pp. 7-9. 
- Marinoni, Giorgio, van't Land, Hilligje, Jensen, Trine, The Impact of Covid-19 on Higher Education around the World: IAU Global Survey Report, International Association of Universities, Paris, 2020.

- Wang, Chuanyi, Cheng, Zhe, Yue, Xiao-Guang, McAleer, Michael, „Risk Management of COVID-19 by Universities in China“, Journal of Risk and Financial Management, Vol 13, No 36, 2020, pp. 1-6.

- Wu, Zunyou, McGoogan, Jennifer M., „Characteristics of and Important Lessons From the Coronavirus Disease 2019 (COVID-19) Outbreak in China: Summary of a Report of 72314 Cases From the Chinese Center for Disease Control and Prevention", The Journal of the American Medical Association, Vol. 323, No. 13, 2020, pp. 1239-1242.

\section{PANDEMIC CRISIS AND THE UNIVERSITY}

Abstract: Global pandemic of COVID-19, unrecorded in modern history, was and still is representing dramatic and unheard-of phenomenon, with deep and universal consequences in global, national and local frameworks. In this work, authors will try to represent and analize the impact of pandemic crisis on academic world, starting with notion that educational system, including higher education, always represented critical infrastructural element, one of the substantial and crucial resources in every community. It is always one of the vital agents of social survival and reproduction. Relying on available informations and sources considering the ongoing global crisis, some aspects, attempts and activities of Chinese universities will be presented, keeping in mind that China was the first country to encounter fullscale epidemic of COVID-19. Central part of the work will deal with the findings and results published in The Impact of COVID-19 on Higher Education in the World: IAU Global Survey Report by International Association of Universities. The Report generally describes and reviews crisis response of 424 respondent universities from 109 countries, from Europe to Asia and Pacific, and from Africa to Americas. Data is collected during March and April, and published in May, therefore during full-swing pandemic. Central role of the work will be dedicated to on-line education, instruction and learning, which emerged as an attempt of sistemic and global response to interruptions of academic life throughout the ongoing pandemic. Many of the universities embraced on-line teaching and learning as a opportunity to keep up with the educational process in pandemic circumstances, including strict measures of social distancing, suspension of public transport, campus closures, etc. This opportunity is realised as a inevitable alternative to interrupted face-to-face teaching and learning, but with variable accomplishment and results. Deeper and more objective evaluation of on-line education in global higher education are yet to be expected, in the context of the prolonged pandemic crisis with comprehensive impact on academic world.

Key words: pandemic, crisis, university, higher education, on-line teaching, learning. 